\title{
Integracja migrantów do struktury miasta i społeczeństwa
} Integration of migrants into the
structure of the city and society

\begin{abstract}
Streszczenie
Procesy globalne, obejmujące wszystkie dziedziny życia nie pozostawiają na uboczu również architekturę. W interesach naukowej wspólnoty jest wyprzedzenie i prognozowanie procesów społecznych. Podczas analizy problemów i tendencji teraźniejszości powstaje nie tylko problem naukowej obserwacji, ale i potrzeba uporządkowywania i skierowywania obiektywnych procesów do potrzebnego i pożytecznego społeczeństwu łożyska. Jednym z takich globalnych zjawisk jest fala międzynarodowej nieuregulowanej migracji, architektoniczny aspekt danego zjawiska zasługuje na oddzielne badanie i wyodrębnienie.
\end{abstract}

\begin{abstract}
Global processes that cover all areas of life do not leave aside architecture as well. Interests of the scientific community have the forecast and prediction of social processes. Analyzing the present problems and trends appears not only the problem of scientific observation, but also the need for ordering and directing objective processes in the necessary channel useful for society. One of such global phenomena is a wave of unregulated international migration, the architectural aspect of this phenomenon deserves a separate study and separation.
\end{abstract}

Słowa kluczowe: mieszkania dla migrantów, integracja migrantów, modeli ulokowania mieszkań, środowisko mieszkaniowe

Tematowi migracji i jej wpływowi na architektoniczne środowisko nie została poświęcona wystarczająca uwaga w architekturniczym naukowym środowisku. Ze względu na kompleksowy zakres zjawiska nieuregulowanej międzynarodowej migracji, znaczenie nowych opracowań w zakresie architektury staje się coraz bardziej oczywiste. Według wyników badań za 2015 rok, które zostały przeprowadzone przez Komisję Europejską, najbardziej aktywnym problemem dla obywateli Unii Europejskiej jest imigracja - która charakteryzuje się napływem imigrantów (chodzi o fale nielegalnej migracji z krajów Północnej Afryki i Bliskiego Wschodu) [10] 38\% ankietowanych stawia to zjawisko na pierwszych miejscach w rankingu najbardziej bolących problemów dla obywateli Unii Europejskiej. W porównaniu z badaniem zeszłorocznym (badanie pokazywało wielkość problemu migracji na poziomie $24 \%$ ), wyniki za 2015 rok wskazują, że problemy związane z wysokim poziomem migracji wyprzedziły takie wyzwania nowych czasów, jak przestępczość, wzrost cen, terroryzm, bezrobocie, sytuacja gospodarcza.

Przyczyną takiego niepokoju Europejczyków jest coraz bardziej aktywna ekspansja migrantów do Europy i nagłośnienie tych wydarzeń w mediach. Niemcy, jako kraj, który otrzymuje najwięcej wniosków od migrantów o uzyskanie azylu, stwierdzają, że według stanu na sierpień 2015 roku otrzymały około 400.000 wniosków od migrantów, a jest to dwa razy więcej niż w 2014 r. [6]. Równocześnie coraz częstsze są masowe za-
The topic of migration and its impact on the architectural environment are not given enough attention in the architectural scientific environment. Taking into account the comprehensive scale of the phenomenon of unregulated international migration, the urgency of developments in the field of architecture is becoming increasingly apparent. According to the results of the European Commission's 2015 surveys, the most urgent problem for the citizens of the European Union is immigration - characterized by an influx of migrants (we are talking about the wave of illegal migration from North Africa and the Middle East). $38 \%$ of respondents put this phenomenon in the top rating of the most urgent problems for EU citizens. Compared to last year's research (the study showed the importance of the problem of immigration at $24 \%$ ), the results for 2015 show that problems associated with high immigration outstrips problems such as crime, price growth, terrorism, unemployment, economic situation . The reason for such anxiety for Europeans is the increasingly active expansion of migrants to Europe and the coverage of these events in media. Germany, as the country that receives most requests for asylum from migrants, notes that as of August 2015, nearly 400,000 requests from migrants have been received, which is twice as much as in 20141. Equally, frequent riots arise with 

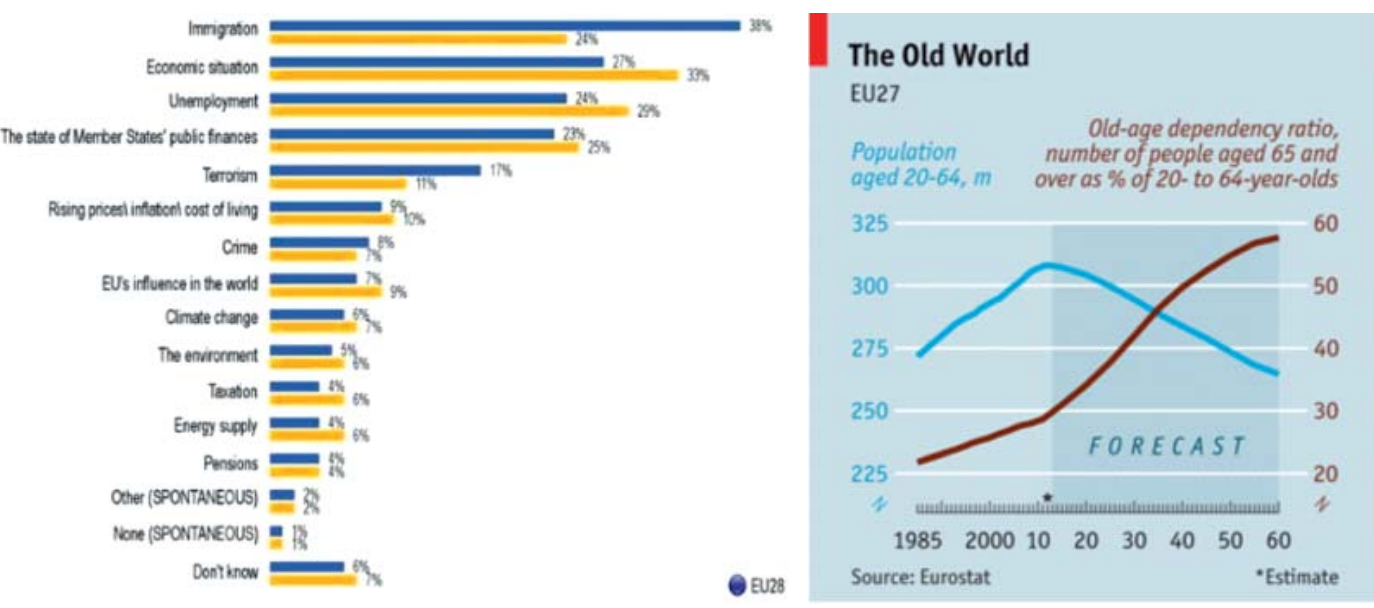

10 Eess 52015

continow $=$

av28

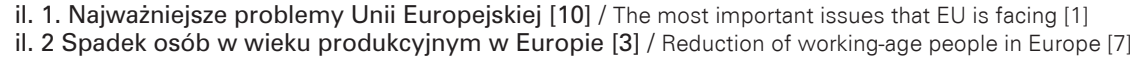

mieszki z udziałem migrantów, którzy starają się przez użycie siły $\mathrm{i}$ efektu tłumu dostać się do Unii Europejskiej lub innego kraju w Europie, przykładem są wydarzenia w mieście Calle (w pobliżu tunelu pod La Manche) [1], na wyspie Lampedusa [5] lub w południowych regionach Grecji [8].

Obserwując tendencję do wyjścia Unii Europejskiej z kryzysu gospodarczego, przezwyciężenia jego skutków, a także tendencję do dalszego rozwoju gospodarczego [4] poszczególne gospodarki Europy pokazują rownież nieznaczny, ale jednak rozwój. Takie wskaźniki są kluczem do napływu migrantów do UE z krajów Afryki Północnej, Bliskiego Wschodu, Europy Wschodniej, Azji. Jest to spowodowane prostym mechanizmem migracji - ludzie migrują z biednych i niebezpiecznych regionów do bardziej rozwinietych regionów, w których są chronione prawa i wolność człowieka. W tym samym czasie, w którym rośnie liczba migrantów, istotny dla krajów UE jest problem starzenia się ludności [3] i przemieszczania w obrębie UE mieszkańców se wschodnich regionów (Rumunia Polsk Butgara) do krajów pótnocno-zachodniej Europy z powodu wyżsego wynajow polnoc [1]. W wyiku tych zrocéów powstaje ni wynagrorówno poszczególnych pracowników wysoko kwalifikowanych jak i nisko wykwalifikowanych zawodów ludzkich.

jadsumowując powyższe, można stwierdzić, że istnieją poPodsumowa ac powyzsen, mozna stwierdzic, ze istnieją powody migacil do krajow UEi igraiczacych znią krajow, a dalsza konfrontacja tego zjawiska nie może wstrzymac tego procesu. Jezeli nie ma możliwosci by oprzeć się obiektywnym procesom - w celu minimalizacji ich negatywnych skutków i optymalizacji wewnętrznego rozsiedlenia należy nimi kierować i korygować, zarówno w odrębnym państwie, które jest członkiem UE, jak i w całej UE lub w sąsiadujących z nią państwami. Przy właściwej regulacji migracji można uzyskać następujące pozytywne tendencje:

napływ ludności w wieku produkcyjnym zmotywowanych do pracy $i$ chcących się zatrudnić $w$ segmencie na rynku pracy, w którym jest małe wynagrodzenie,

- wzrost liczby ludności i zmiana sytuacji demograficznej (tylko w przypadku pomyślnej integracji i stopniowej asymilacji migrantów z nowym społeczeństwem);

- wzbogacenie kulturalne kraju. the participation of migrants who seek to get into the EU or another European country through the in the city of Calle (near the tunnel under the La Manche ${ }^{2}$ on the island of $L^{2}$ mpedusa ${ }^{3}$ or in the southern regions of Greeces.

Following the tendency for the EU to exit the economic crisis, overcoming its consequences, as well as further economic development, shows a slight but, nevertheless, development of the European economy. Such indicators are the key to keeping the influx of migrants to the EU from North Africa, the Middle East, Eastern Europe, and Asia. This is explained by the simple mechanism of migration - people migrate from poor and more where human rights and freedoms are provided and protected.

At the same time as the growing number of migrants is relevant for EU countries, the problem of population aging ${ }^{5}$ and the flow of people from the eastern regions (Romania, Poland, Bulgaria) to the countries of north-western Europe due to higher wages 6 . As a result of such processes, a deficit is created for highly specialized as well a simple low-skilled professions.

menclude tha has a foundation, and further confrontation with this phenomenon can not delay this process. resistance to objective processes is not possible they should be guided and adjusted in order to minimize their negative influences and optimize their internal situation both in the individual $E U$ member state and in the whole EU or neighborin countries. With proper adjustments migration can get such positive trends:

- The income of people of working age, motivated to work and employ

- population growth and demographic change (only if successfuly integrated and gradual assimilatio of migrants into a new society)

- Cultural enrichment of the countries.
Segregacja migrantów zarówno w społeczeństwie, jak i w strukturze miasta. Zjawisko to jest wynikiem upizedzen wobec migrantów i samoorganizacji mieszkalnych formacji migrantów, które opierają się na dotowanej pomocy państwa w postaci świadczeń finansowych i kursu priorytetowych szkoleń, dla przyspieszenia integracji migrantów z nowym społeczeństwem. Wada takiej pomocy migrantom jest niekontrolowane ich rozsiedlanie w strukturze miasta (lub innych osiedlach). Państwowy mechanizm

na uprościć do takiego algorytmu:

- zatrzymanie migrantów przez władze państwowe:

- pobyt migranta $w$ punkcie tymczasowego utrzymywania w którym odbywa się identyfikacja, wyjawienie przyczyn migracji i wyjaśnienie możliwość pobytu w kraju;

po ukończeniu wszystkich procedur w miejscu tymczasowego utrzymywania odbywa sie albo deportacja z kraju, albo udzielane jest zezwolenie na pobyt.

Jeżeli migrant uzasadni niemożliwość powrotu do swojej ojczyzny i brak własnego finansowego zabezpieczenia, $w$ takim wypadku często jest mu udzielana dotacja finansowa.

Po uzyskaniu zezwolenia na pobyt i wsparcia finansowego $\mathrm{mi}$ grant staje przed wyborem - albo asymilować się do nowego społeczeństwa bez podtrzymywania związkow z sobie podobnymi w planie identyczności etnicznej, religijnej czy kulturanej, albo szukac blizszych związkow z nimi. W celu minimalizacji negatywnego wpływu nowego środowiska i unikania stresowych sytuacji podczas zmiany własnego zachowania i myślienia większość ludzi w nowym środowisku poszukuje ludzi spokrewnionych. Konsekwencją tych procesów jes integracja imigrantów, nie tylko podczas codziennego bytu, poszukiwania pracy, ale i podczas poszukiwania zakwaterowania, co wyraża się bliskością zamieszkiwania imigrantów względem siebie. Dalsza akumulacjia migrantów prowadzi do tworzenia różnych rodzajów gett - etnicznego, kulturowego tak zwane getta nazywa sie -

Negatywnym przejawem zjawiska gettoizacjì jest zmniejsze-

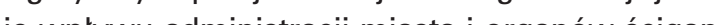

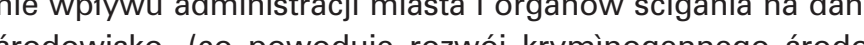
srodowisko, (co pow duje rozwj kymogennego srodo(0, 7l, ora degracio

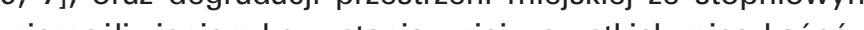
uniemozzliwieniem korzystania z niej wszystkich mieszkańcó

Integracja migrantów jest zawsze procesem dwukierunkowym, zachodzi z udziałem zarówno migrantów, jak i społeczeństwa które ich akceptuje. Jednocześnie integracja nie dotyczy tylko kultury czy rynku pracy. Jest to także kwesti dostępu do życia społecznego i politycznego, do opieki zdrowotnej. To sprawy, związane z pobytem, bo brak uregulowanego statusu hamuje właśnie integrację. Przyjmuje się, że w pełnym wymiarze ona ma miejsce wtedy, kiedy migranci otrzymują praktycznie takie same prawa, jak rdzenni mieszkancy panstwa, kiedy ostatecznie stają się jego obywatelami. Należy pamiętać, że integracja to nie jest asymilacja. Ona jako dwustronny proces, nie przewiduje stuprocentowego zlania się migrantów ze społeczeństwem, które ich przyjmuje.
Segregation of migrants both in society and in the city structure. Such a phenomenon is the result of a biased attitude towards migrants and the selorganization of migrant settlements, based on subsidized state support in the form of financial assistance and a course of trainings to accelerate such a sionton a new society. The disadvantage of of its resettlement in the structure of the city (or other settlement). The state mechanism for working with migrants can be simplified to such algorithm:

detention of a migrant by state authorities;

stay of a migrant in a place of temporary detention, where the identification of a person the motivation of migration and the possibility of residing in the country;

after passing all procedures at the place of temporary detention either the deportation of the If a migrant argues that it is impossible to retunce. his homeland and lack his own financial suppot he often receives a financial grant.

After obtaining a residence permit and financia support, a migrant has a choice - or to enter a new society without the support links to his own ethnic religious or cultural identities, or is looking for the closest ties with them. Most people get into a new environment are looking for related people, to minimize the negative impact of the new environment and avoid stress in changing their own behavior and mind set. The consequence of only in finding is hom agyegat in fingrants not which is expressed by the proximity of habits relative to one another. A further accumulation of migrants leads to the creation of a different kind of ghetto - ethnic, cultural or social. The process of transformation of the city's territory to the socalled ghetto is called - ghettoization.

Negative consequences of the phenomenon of ghettoisation are the reduction of the influence of the city administration and law enforcement agencies on the environment (which leads the rise of a crime rates with all the emerging circurnstances) 9 and degradation of urba by all residents of the city.

Integration of migrants is always a two-way by al resid of the city. both migrants and the host society. At the same ime integration does not only concern cult the labor market. It is also a matter of access to public and political life, to the health care system. This is a matter of residence, because the lack of status impedes integration. It is believed that it is taking full scale when migrants receive practically the same rights as the cilizens of the state they finally become its citizens. At the same time, a two-way process, does to assimilation. It, as merge of migrants with the host society. Here must be space for cultural needs and the culture of migrants in particular. 
Tu, w szczególności, powinien być stworzony obszar dla kulturalnych potrzeb i specyficznej kultury migrantów.

Należy zaznaczyc, ze własciwa integracja zawsze pozwala korzystać z potencjału migrantów, przynosząc korzyść im i catemu społeczeństwu. Jednocześnie integracja na osobistym poziomie jest związana z pewnymi psychologicznymi procesami. Dla przykładu: już naukowo udowodniono, że brak możliwości rozwoju swojej kulturalnej identyczności albo wstydzenie sie jej mozie kończyć sie depresia albo nawet samobójstwem. Czesto ludzie którzy całkowicie sie zasymaruchów,

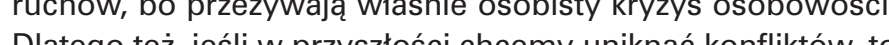
Dlation, to spoleczens je, kore przy muje migrantow ha poziomie pań stwowym i na poziomie miejscowym powinno sprzyjac za-

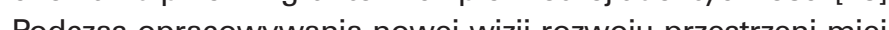
Podczas opracownania nowej wizli rozwoju przestrzeni miej. skiej i przestzeni miasta w calości, konieczne jest zwrócenie uwagi na globalne tendencje, w szczególności na zjawisko migracji. Umiejętne uporządkowanie takiego wieloskalowego wezwania, jak migracja może dostarczyć nowych korzyści gospodarczych i wytyczyc nowe trendy spoleczne (jest to niezgodne ze stereotypem negatywnych postaw wobec wszystkich obcych migrantów i migracji jako procesu). Lekkomyślne zignorowanie rozwiązania danego wezwania moze doprowadzić do negatywnych tendencji jak w społeczenstwie, tak i w strukturze miasta. Dla integracji migrantów ze społecznością miasta zostały opracowane modele ulokowania ich mieszkan w zabudowie. Rozpartywany jest przykład rozmieszczenia mieszkań dla migrantów $w$ istniejącej i projektowanej zabudowie mieszkalnej w budynkach publicznych i przemysłowych. W celu uniknięcia koncentracji migrantów w środowisku miejskim i zjawiska getta, podczas planowania ulokowania mieszkań dla imigrantów trzeba przestrzegać zasad dyspersyjnego rozsiedlania.

Ulokowanie mieszkań dla migrantów może odbywać się wg następujących modeli:

- ulokowanie mieszkań dla migrantów w istniejącej zabudowie mieszkalnej

ulokowanie mieszkań dla migrantów w projektach zabudowy mieszkalnej:

ulokowanie mieszkań dla migrantów w zabudowaniami sosjalnych;

ulokowanie mieszkań dla migrantów w zabudowaniach przemysłowych i produkcyjnych

\section{Ulokowanie mieszkań dla migrantów w istniejące}

\section{abudowie mieszkaln}

Podczas rozpatrywania tego modelu należy rozpatrzyć dwie wizje:

1. Rozmieszczenie migrantów w jednym z lokali mieszkalnych. Taka metoda rozsiedlenia eliminuje zmiany konstrukcyjne w strukturze budynku z udziałem znacznych kosztów finansowych. Ze względu na możliwe minimalne wyrównywanie dopuszczalnych standardów przestrzeni zyciowej, mieszkanie może służyć dla indywidualnego pobytu kilku migrantów lub jako kwatera dla grup migrantów. Zaletą tej metody zakwaterowania jest bezpośredni kontakt migrantów $\mathrm{z}$ rdzenna
It should be noted that integration allows the society as a whole. A

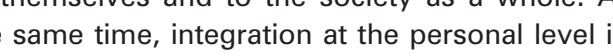
associated with certain psychological processes. or example, it has already been scientifically proven that impossibility to develop ones cultura Often people who have completely assimilated unexpectedly became members of some radica movements, because they were experiencing a personal crisis of identity. Therefore, if in the future we want to avoid conflicts, the host society at the state level and at the level of local communities should help migrants to preserve their origina identity ${ }^{9}$.

In the process of creating a new urban space and the city as a whole, it is necessary to take into accoun global trends, in particular the phenomenon of migration. Adequate management of such largescale challenges as migration can bring new conomic benefits and socially important trend (we are talking about combating the stereotype migrants and migration as a process) On the els time ignoring of the solution to this challenge can lead to negative trends in both society and city structure.

For integration of migrants into the structure of the city, models of housing integration were worked out in public and industry buildings. When integrating housing for migrants, the principle of dispersal resettlement should be respected, in order to avoid the concentration of migrants in the urban environment and avoid the phenomeno of ghettoisation. This can be divided into the following models:

- integration of housing for migrants in existing housing development;

- Integration of housing for migrants in planed

for migrants in public

egration of housing for migrants in industria facilities and production.

Integration of housing for migrants into existing housing

When considering this question, one should focus on two visions:

1. Integration into one of the residential apartments. This method of integration avoids signifcant interventions in the structure of the house, therefore avoids significant financial costs. On account of possible alteration to the minimum are residence for deveral migrants or as housing for group-type settlements. The advantage of this settlement method is the direct contact with the indigenous population, which prompts the socialization of the migrant, which in turn is useful to society. Another advantage is that this method can be tested on the real estate market. Such characteristic

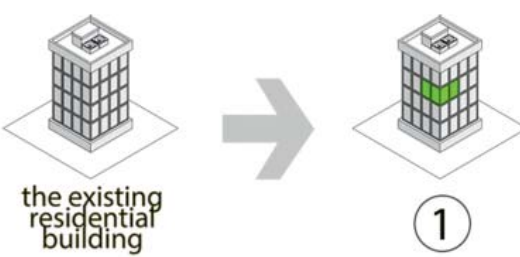

il. 3. Schemat modeli ulokowania mieszkań dla migrantów wistniejacej zabudo-
wie mieszkalnej/ Scheme of integration of housing for migrants into existing housing

ludnością, który prowadzi do przyśpieszenia uspołecznienia migrantów, co z kolei jest korzystne dla społeczeństwa. Kolejną zaletą takiego rozsiedlenia jest to, że metoda ta może być wprowadzona przez wykorzystanie dużej ilości ofert na rynku nieruchomości, które mają dowolną lokalizację. Takie cechy sprzyjają stosowaniu dyspersyjnej metody rozsiedlania.

2. Rozmieszczenie migrantów $w$ pomieszczeniach niemieszkalnych, takich jak suterena lub niewykorzystywane poddasze. Podczas urządzania mieszkań dla migrantów w niemieszkalnych lokalach suteren i poddasza, powstają problemy z przebudową i przystosowaniem pomieszczeń do funkcji mieszkaniowej. Zaletą tego modelu wykorzystania mieszkan dla migrantów jest przede wszystkim możliwość jego wykorzystania, bez zakłócania porządku istniejących mieszkań W tym modelu główne zastrzeżenie dotyczy braku zapobieganie alienacji i separacji migrantów od mieszkańców domu.

\section{Ulokowanie mieszkań dla migrantów w projektowane}

Projektując nowy budynek mieszkalny mogą być zastosowane następujące podstawowe modele:

1) Ulokowanie mieszkań dla migrantów w jednym z mieszkan budynku mieszkalnego;

2) Ulokowanie mieszkań dla migrantów w niemieszkalnych pomieszczeniach takich jak sutereny i poddasza;

3) Ulokowanie migrantów i rdzennej ludności w jednym budynku mieszkalnym z równoczesnym zapewnieniem terenu dla komunikacji na przybudynkowym obszarze. Dany model prze-

only contribute to the use of the disperse method of resettlement.

. Integration into non-residential premises, such as a socle or non-exploited attic. When housing for migrants in the non-residential premises of the base and attic there are structural problems of refunctions. The advantage of this integration mode for migrants to others are the wide possibilities of use without interference with existing living quarters. With this model, the main precondition for use is to prevent segregation of migrants from home residents.

Integration of housing for migrants into planed

When designing a new dwelling house, the following principal models are proposed:

1) Integration of housing for migrants into one of the apartment houses of the house;

2) Integration of housing for migrants in non-residential premises of the attic and a socle;

3) Equal settlement of migrants and indigenous people in a residential building, with the establishment of communicative space in the adjoining area. This model involves the concentrated accommodation of migrants in a residential building on the territory of settlements. Communotes space should be a connecting factor for an everyday living. This model can be used both for socia housing and for various types of dormitories. An mportant component of this model is comparable social, age, professional groups of migrants and indigenous people, in order to avoid domestic conflicts.

4) The combination of dwelling houses (or parts thereof) through the rooms of mutual use for the indigenous population and migrants. Such a model involves creating a connecting locatio schoot or gymnasium for sports. This model op-

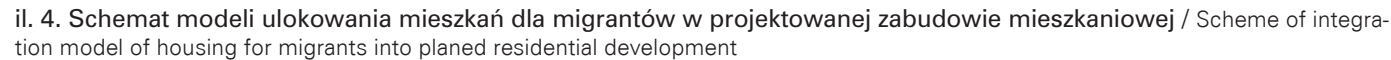

ili. 4. Schemat modeli ulokowania mieszkań dla migrantów $w$ pro
tion model of housing for migrants into planed residential develooment

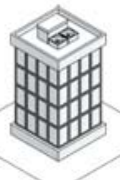

the existing
resiogntial
building
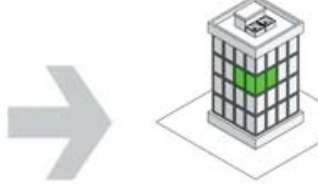

(1)

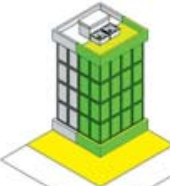

(3)

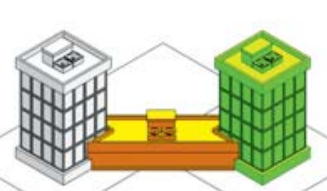

(4)

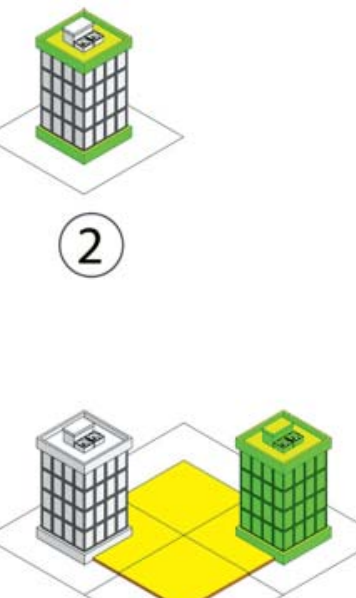

(5) 
widuje skoncentrowany pobyt migrantów w jednym budynku mieszkalnym, lecz wylacza koncentracje takich modeli na terenie osiedla. Przestrzeń dla komunikacii mieszkańców powinna być jednoczacym czynnikiem w codziennym życiu. Model ten może być zastosowany zawowno do mieszkań socjalnych jak i dla różnych typów (internatów) hoteli. Ważnym elementem tego modelu jest profesjonalne dobranie społeczne, wieku grupy migrantów i rdzennej ludności, aby uniknać konfliktów. 4) wykorzystanie budynków mieszkalnych (lub ich cześcil jednocześnie dla rdzennej ludności i migrantów wyposażenie iedw pomieszczenia do wspómego uzitku. Model ten polega

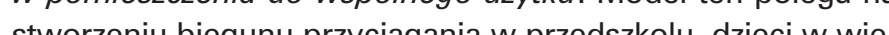
ku szkoly lub up rawiaiu spotów rekreacy,

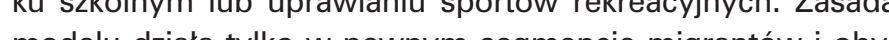

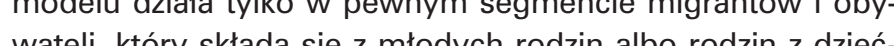

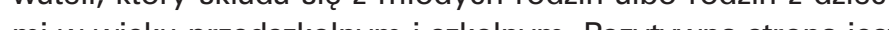
mi w wieku przedszkolnym i szkolnym. Pozy roną stroną jest możliwośc rozsiedlania grupy migrantow o duży potencjale integracji z lokalnym spoleczenstwem przez wczesną integrację dzieci migrantów z mieszkańcami. Wadą tego modelu jest duża koncentracja migrantów, co ogranicza zakres jej zastosowania, $w$ celu zapobiegania segregacji i hettoizacji.

5) wykorzystanie budynków mieszkalnych (lub ich części) jednoczesnie dla rdzennej ludnosci i migrantów, przez organizowanie przestrzeni i placów dla wspólnego użytku. W modelu tym widac istotne zastrzeżenia co do skuteczności motywowania migrantow do integracji z ludnością rdzenną. Koncentracja migrantów w osobnym budynku mieszkalnym, który nie jest połączony z mieszkalnymi jednostkami dla rdzennej ludności stwarza warunki do samoistnej alienacji migranta. Powstaje ryzyko odbudowy zwykłego dla migranta modelu społeczeństwa, izolującego sie od nowych otaczających warunków.

\section{Ulokowanie mieszkań dla migrantów w budynkach uży-}

\section{teczności publiczne}

Model pokazuje możliwość umieszczania mieszkań dla migrantów w sieci placówek publicznych (takich jak centra handlowe biurowce, itp). Koncepcia danego modelu jest wspófbrzmiaca z opracowanimi grupy architektów Instytutu Architektury Potudniowej Karoliny, USA (Caroline Dahl, Robert Cha, Hossein Lotfi Shemirani), która pokazuje ideę połączenia mieszkań klasy elit z mieszkaniem dla migrantów pracujących i obsługi [2]. W odróżnieniu od poprzednich modeli ulokowania mieszkań dla migrantów, dane rozwiązanie potrzebuje wyraźnego rozgraniczenia komunikacyjnych ciągów dla interesantów danego obiektu społecznego i bezpośrednio migrantów.

\section{5. Schemat modeli ulokowania miesskań dla migrantíw w budynkach ü̇y
teczności publicznej / The scheme models the integration of housing for migrants.}
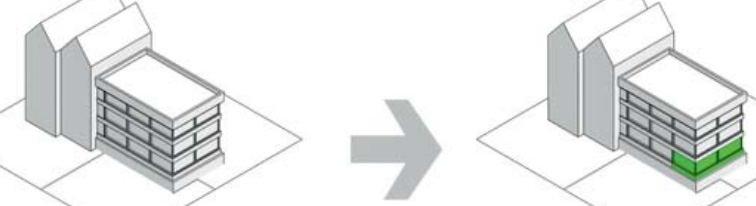

public buildings erates only in a specific segment of migrants and citizens, which consists of young families or persons with children of preschool, school age. The positive aspect of the feature is the possibility of resettlement of a group of migrants with a grea potential for integration into society - due to the The sisialzation of migrant children into society concentration of migrants, which reduces the range of its use.

5) The combination of residential buildings (or parts thereof) for indigenous people and migrants through the arrangement of spaces and areas for sharing.The proposed model has significant reservations about the desire of migrants to integrate into society. The concentration of migrants in a separate dwelling house, which is not connected creates conditions for the unilateral segregation of the migrant from the new conditions of society there is a risk of rebuilding the model of society common to the migrant, isolating themselves from the new environment.

Integration of housing for migrants in public facilities

The model shows the possibility of integration into the network of public facilities (such as shopping and other housing for migrants). The concept of this model is conformable to the developments of the architects of Architecture Institute of South Carolina, USA (Caroline Dahl, Robert Cha Hossein Lotfi Shemirani), which shows the idea of combining public housing and housing of an elite class with housing for migrant workers and service staff 10 . ike previous models of housing for migrants, this solution requires a clear separatio buildings and direct workers.

Integration of housing for migrants in industria facilities and production

When considering the possible integration of housing for migrants into the structure of industrial buildings and production, two models of integration are proposed:

1) the integration of housing outside the sanitary protection zone of an industrial site. This housing model is often used in practice in the form of developing countries shows, this type of housing is exploited by labor migrants from countries with lower levels of economics and lower wages.

2) the integration of housing for migrants in the very structure of the industrial facility, but only in the demarcation by the administrative zone of residential and industrial.

Conclusions

for anterice describes the scale of the phomo social significance of this phenomenon. In the presence of this phenomenon in the society there is a request regarding developments in the field of

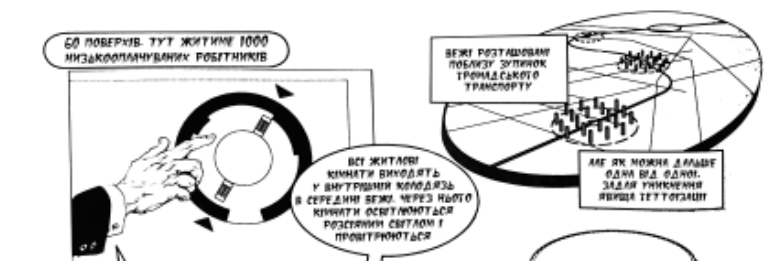

(a)
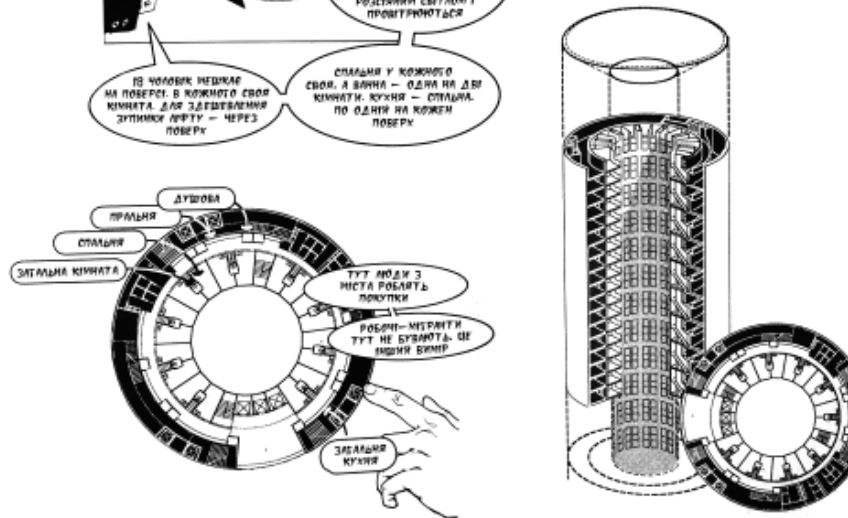
il. 6. Propozycja grupy architektów Instytutu Architektury Potudniowej Karoli-
ny, , SA (Caroline Dahl, Robert Cha, Hossein Lotri Shemirani) (2)/ Proposal by
a group of architects at the Institute of Architecture in South Carlina, USA I Caroline Dahl, Robert Cha, Hossein Lottitute of Anil

Ulokowanie mieszkań dla migrantów w przemysłowych produkcyinych zabudowaniach

Podczas rozpatrywania możliwej lokalizacji mieszkań dla migrantów w strukturze zabudowań przemysłowych i produkcyjnych zostaly zaproponowane dwa modele rozmieszczenia: 1) ulokowanie mieszkan poza sanitarną strefą ochrony obiektu przemystowego. Dany model mieszkan często jest wykorzystywany w praktyce pod postacią internatów (akademików hoteli) dla pracowników. Jak pokazuje doświadczenie krajów z rozwijającą się gospodarką, dany rodzaj mieszkań jest eksploatowany przez migrantów pracujących pochodzących z krajów o niższym poziomie gospodarki i nizszej płacy.

2) ulokowanie mieszkań dla migrantów w strukturze przemystowego obiektu, ale tylko rozgraniczając administracyjna strefę od mieszkalnej i produkcyjnej.

Wnioski. W artykule została opisana skala zjawiska nielegalnej migracji i zdawkowo przedstawiona ważność społeczna danego zjawiska. Jeżeli istnieje dane zjawisko w społeczeń stwie to powstaje pytanie co do zasobów danych w zakresie architektury dotyczacych uporzadkowania i ukierunkowanie

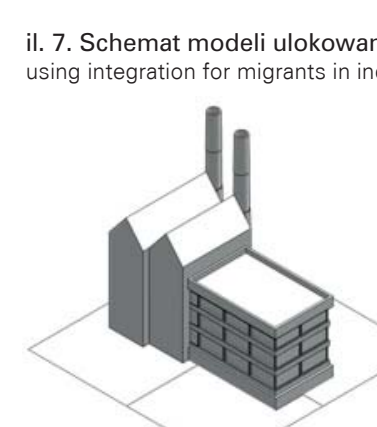

indugtrial

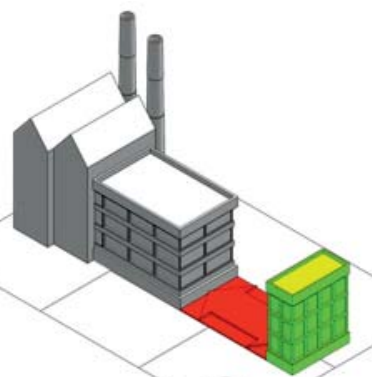

(1) architecture in ordering and directing migration in a useful channel of society.

The problem of ingot of migrants into society as one of the solutions to the problem of the phenomenon of migration is represented as construction locality. It is proposed to use in the practice of differentiated models of housing for migrants in the following groups: the integration of housing for migrants in existing residentia development, integration of housing for migrants in projected residential development, integratio of housing for migrants in public buildings, housing for migrant integration in buildings and

Each of the architectural models of integration of housing for migrants has both disadvantages and integration models, you need to set the or the indicators, as well as get a warning about possible problems. Using the proposed approach increases the likelihood of successful integration of migrants into a new environment, which is the key to solving this global phenomenon as internationa migration.

ENDNOTES:

for foreign secretaryy / the Guardian, 10 cepnirg 2015 pory pory com/uk-news/2015/aug/09/african-migrants-threaten-eu"Calais crisis: Migrants exploit strike chaos as port and

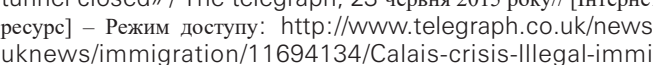
grants-shut-down-all-Channel-traffic.html "Lampedusa in Focus: Migrants Caught between the
Libyan Desert and the Deep Sean / Rutvica Andrijasevic pp. $120-125 /$ - Pe.⿲丿丨 4Migrants in Greece: The struggle for a better life

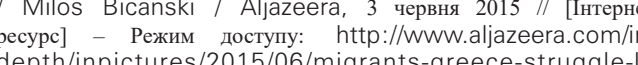
fe-150602111642000.html "European demography. Working-age shift» / The
economist, 26 cimня 2013 pory // [Hтrepнer pecypc] - Режим hocryny:
anttp://www.economist.com/news/finance
and-economics/21570752-growth-will-suffer-workers -dwindle-working-age-shi

"Z Polski emigruje coraz więcej specjalistów - wśród nich lekarze i pielegniarki, / ynnekzdrowia.pl, 17 kвirнk 2015 
korzystnego społecznie rozmieszczania przybyszów. Problem wlewania się do społeczeństwa migrantów, jako jednej z dróg rozwiązania problemu zjawiska migracji, został zaprezentowany pod postacią modeli ulokowywania mieszkań dla migrantów w zastosowaniu budownictwa mieszkaniowego miejscowości.

Zostało zaproponowane zastosowanie na praktyce różnych modeli mieszkań dla migrantów wg następujących grup: ulokowanie mieszkań dla migrantów w istniejącej zabudowie mieszkalnej, ulokowanie mieszkań dla migrantów w projektowanej zabudowie mieszkalnej, ulokowanie mieszkań dla migrantów w zabudowaniach społecznych, ulokowanie mieszkań dla migrantów w zabudowaniach przemysłowych i produkcyjnych. Każdy z przedstawionych architektonicznych modeli rozmieszczenia mieszkań dla migrantów posiada zarówno wady, jak i zalety. Podczas wyboru jednego z modeli rozmieszczenia lokali trzeba wybrać priorytetowe cechy, a także zapoznać się z możliwymi problemami.

Korzystając z proponowanego podejścia zwiększa się prawdopodobieństwo udanej integracji migrantów z nowym środowiskiem, które jest kluczem do rozwiązania takiego globalnego zjawiska jak migracja międzynarodowa.

\section{LITERATURA}

[1] Calais crisis: Migrants exploit strike chaos as port and tunnel closed (2015 23 czerwca). The telegraph. Pozyskano z: http://www.telegraph.co.uk/news/ uknews/immigration/11694134/Calais-crisis-Illegal-immigrants-shut-down-all-Channel-traffic.html

[2] Caroline Dahl, Robert Cha, Hossein Lotfi Shemirani (2009, maj). Журнал по мировой архитектуре ПI22, Печать ОАО «Типография Новости». SS. 52-60.

[3] European demography. Working-age shift (2013, 26 stycznia). The economist. Pozyskano z: http://www.economist.com/news/finance-and-economics/21570752-growth-will-suffer-workers-dwindle-working-age-shift

[4] Henry Foy and Claire Jones. All EU economies set to expand for first time since crisis (2015, 28 maja). Financial Times. Pozyskano z: http://www.ft.com/ $\mathrm{cms} / \mathrm{s} / 0 / 2064 f 4 a 8-0457-11$ e5-a5c3-00144feabdc0.html\#axzz3ia0xkHuN

[5] Milos Bicanski. Migrants in Greece: The struggle for a better life (2015, 3 czerwca). Aljazeera. Pozyskano z: http://www.aljazeera.com/indepth/inpictures/2015/06/migrants-greece-struggle-life-150602111642000.html

[6] ,Marauding' migrants threaten standard of living, says foreign secretary (2015, 10 sierpnia). The Guardian. Pozyskano z: http://www.theguardian.com/uk -news/2015/aug/09/african-migrants-threaten-eu-standard-living-philip-hammond

[7] Marlise Simons. Amsterdam Tries Upscale Fix for Red-Light District Crime (2015, 24 lutego). The New York Times. Pozyskano z: http://www.nytimes. $\mathrm{com} / 2008 / 02 / 24 /$ world/europe/24amsterdam.html?pagewanted=all\& $r=0$

[8] Rutvica Andrijasevic . Lampedusa in Focus: Migrants Caught between the Libyan Desert and the Deep Sea (2006) Feminist Review, No. 82, Everyday struggling , pp. 120-125. Pozyskano z: http://www.jstor.org/stable/3874452?seq=1\#page scan tab contents

[9] Soeren Kern . Police Warn of No-Go Zones in Germany (2015, 1 sierpnia). Gatestone Institute. Pozyskano z: http://www.gatestoneinstitute.org/6264/no-go-zones-germany

[10] Spring 2015 Standard Eurobarometer : Citizens see immigration as top challenge for EU to tackle (2015, lipiec). Strona internetowa Komisji Europejskiej. Pozyskano z: http://europa.eu/rapid/press-release_IP-15-5451_en.htm

[11] Z Polski emigruje coraz więcej specjalistów - Wśród nich Tekarze i pielęgniarki (2015, 17 kwietnia) Rynekzdrowia.pl. Pozyskano z: http://www.rynekzdrowia pl/Po-godzinach/Z-Polski-emigruje-coraz-wiecej-specjalistow-wsrod-nich-lekarze-i-pielegniarki, 150877,10.html

[12] Захарова Т.А. Соціалізація дошкільника як чинник розвитку компетентності майбутньої особистості (2015, maj). Young Scientist, № 5 (20), Part 3 . Pozyskano z: http:// molodyvcheny.in.ua/files/journal/2015/5/106.pdf

[13] Яніна Овчарек. Інтеграція - це не асиміляція (2014, 16 listopada ). Наш вибір. Газета для украӥнців в Польщі. Pozyskano z: http://naszwybir.pl/int/
pl/Po-godzinach/Z-Polski-emigruje-coraz-wiecej-specjalistow-wsrod-nich-lekarze-i-pielegniarki,150877,10.html

7 "Police Warn of No-Go Zones in Germany» / Soeren Kern / Gatestone Institute, 1 серпня 2015 // [Інтернет ресурс] - Режим доступу: http://www.gatestoneinstitute.org/6264/no-go-zones-germany

8 «Amsterdam Tries Upscale Fix for Red-Light District Crime» / Marlise Simons / The New York Times, 24 лютого 2008 // [Інтернет ресурс] - Режим доступу: http://wWW. nytimes.com/2008/02/24/world/europe/24amsterdam. html? pagewanted $=$ all _ $r=0$

9 «Інтеграція - це не асиміляція» / Яніна Овчарек / Наш вибір. Газета для українців в Польщі, 16 листопада 2014 // [Інтернет ресурс] Режим доступу: http://naszwybir.pl/int/

${ }^{10}$ Caroline Dahl, Robert Cha, Hossein Lotfi Shemirani, Southern California institute of architecture, KDG, Журнал по мировой архитектуре ПІ22, Мау 2009, pp.52-60. Печать ОАО «Типография Новости».

\section{BIBLIOGRAPHY}

[1] Calais crisis: Migrants exploit strike chaos as port and tunnel closed (2015, 23 June). The telegraph. Online source, link: http://www.telegraph.co.uk/news/uknews/ immigration/11694134/Calais-crisis- Illegal-immigrants-shutdown-all- Channel-traffic.html

[2] Caroline Dahl, Robert Cha, Hossein Lotfi Shemirani (2009, May). Журнал по мировой архитектуре ПІ22, Печать ОАО «Типография Новости». pp. 52-60

[3] European demography. Working-age shift (2013, 26 January). The economist. Online source, link: http://www. economist.com/news/finance-and- economics/21570752growth-will- suffer-workers- dwindle-working- age-shift

[4] Henry Foy and Claire Jones. All EU economies set to expand for first time since crisis (2015, 28 May). Financial Times. Online source, link: http://www.ft.com/ $\mathrm{cms} / \mathrm{s} / 0 / 2064 f 4 a 8-0457-11$ e5- a5c3-00144feabdc0. html\#axzz3ia0xkHuN

[5] Milos Bicanski. Migrants in Greece: The struggle for a better life (2015, 3 June). Aljazeera. Online source, link: http://www.aljazeera.com/indepth/inpictures/2015/06/ migrants-greece-struggle- life-150602111642000.html

[6] "Marauding" migrants threaten standard of living, says foreign secretary (2015, 10 August). The Guardian. Online source, link: http://www.theguardian.com/uknews/2015/ aug/09/african-migrants- threaten-eu- standard-living- philiphammond

[7] Marlise Simons. Amsterdam Tries Upscale Fix for RedLight District Crime (2015, 24 February). The New York Times. Online source, link: http://www.nytimes.com/2008/02/24/ world/europe/24amsterdam. html? pag ewanted =all\&amp; $r=0$

[8] Rutvica Andrijasevic . Lampedusa in Focus: Migrants Caught between the Libyan Desert and the Deep Sea (2006) Feminist Review, No. 82, Everyday struggling pp. 120-125. Online source, link: http://www.jstor.org/ stable/3874452?seq=1\#page_scan_tab_contents

[9] Soeren Kern . Police Warn of No-Go Zones in Germany (2015, 1 August). Gatestone Institute. Online source, link: http://www.gatestoneinstitute.org/6264/no-go- zonesgermany

[10] Spring 2015 Standard Eurobarometer : Citizens see immigration as top challenge for EU to tackle (2015, July). Strona internetowa Komisji Europejskiej. Online source, link: //europa.eu/rapid/press-release_IP-15-5451_en.htm

[11] Z Polski emigruje coraz więcej specjalistów - wśród nich lekarze i pielęgniarki (2015, 17 April) Rynekzdrowia.pl. Online source, link: http://www.rynekzdrowia.pl/Po-godzinach/ZPolski-emigruje- coraz-wiecej- specjalistow-wsrod- nichlekarze- i-pielegniarki, 150877,10.html

[12] Захарова Т.А. Соціалізація дошкільника як чинник розвитку компетентності майбутньої особистості (2015, May). Young Scientist, 5 (20), art 3 . Online source, link: http://molodyvcheny. in.ua/files/journal/2015/5/106.pdf

[13] Яніна Овчарек . Інтеграція - це не асиміляція (2014, 16 November ). Наш вибір. Газета для українців в Польщі. Online source, link: http://naszwybir.pl/int/ 